\title{
STIRLING MOTOR MODELLEZÉSE
}

\author{
Mészáros Károly Marcell - Pozsa Ákos - Illés Tamás - Tollár Sándor - \\ Tolvaj Béla - Bencs Péter
}

\begin{abstract}
Absztrakt: A cikkben a Stirling gépekben lejátszódó termodinamikai folyamatok számítására alkalmas numerikus eljárást ismertetünk. A munkaközeg áramlását egydimenziós, instacionárius, nem izentrópikus gázáramlásként modellezzük. A Stirling gépben lejátszódó körfolyamatot a mozgás-, a kontinuitási- és az energiaegyenletből álló parciális differenciál-egyenlet rendszerrel írjuk le, amelyet a karakterisztikák módszerével oldunk meg. Részletesen ismertetjük a megoldáshoz szükséges kezdeti- és peremfeltételek előállítását és az egyes térrészek összekapcsolását leíró egyenletrendszert. A módszer alkalmazhatóságának igazolására egy konkrét számítási példát is megoldunk.
\end{abstract}

\begin{abstract}
This article describes a numerical method for calculating thermodynamic processes in Stirling machines. The flow of the fluid is modeled as a one-dimensional, stationary, non-isotropic gas flow. The process in the Stirling machine is described by a partial differential equation system consisting of motion, continuity, and energy equation, which is solved by the characteristic method. The preparation of the initial and boundary conditions for the solution is described in detail and system of equations describing the interconnection of each space. A specific calculation example is also provided to prove the applicability of the method.
\end{abstract}

Kulcsszavak: Stirling, hötechnika, szimuláció

Keywords: Stirling, heat engineering, simulation

\section{Bevezetés}

Robert Stirling lelkész találta fel 1816-ban. Az első gépeken lényeges újításokat dolgozott ki, majd beadta az első szabadalmat rá. Később segített mérnök fivérének, James Stirlingnek a további fejlesztésekben. A feltalálók szándéka az volt, hogy olyan hőerőgépet dolgozzanak ki, amely biztonságosabb, mint a korabeli gőzgépek, melyek kazánjai gyakran robbantak fel a nagy gőznyomás és a nem megfelelő anyagok használata miatt. Elterjedésük Angliában és Amerikában kezdődött meg. A gázmotorok, gőzgépek, Otto- és a Diesel-motorok megjelenésével ez a szabadalom háttérbe szorult mivel a fajlagos teljesítménye sokkal kisebb volt. Manapság újra elötérbe kerülhet ez a konstrukció a környezetvédelmi intézkedések és célok miatt. Elektromos energiát előállítani a házilag megoldható eszközökkel nem olcsó. A napelemeknek nagy a beruházási igénye és lassú a megtérülése. A szélgenerátorok kevés helyen tudnak adni megbízható teljesítményt. A Stirling motor külsőégésű, ezért az üzemanyag elégetése a motoron kívül történik. Ebből kifolyólag az égés könnyebben kontrolálható a belsőégésü motorokhoz képest. A Stirling motor müködéséhez szükséges hőt, mint energiaforrást magunk is megtermelhetjük, vagy a Naptól vételezhetjük. A fütéskori forró füstgázok még sok hasznosítható energiát tartalmaznak a Stirling motor számára, de a Stirling motor hulladékhője is hasznosítható a fütés visszatérő ágában. A Stirling motor számára telepített napenergiás hőtermelő kapacitás a fütési szezonban a lakást fütheti, a szezon után pedig áramot termelhet. A Stirling folyamat megfordítható. Ilyenkor hőszivattyúként müködik. A motor tengelyének a forgatásával jelentős hőmérséklet csökkenést, akár 
abszolút nulla fokot megközelítő hőmérséklet is elérhető. Gazdaságosabb ez a módszer, mint a jelenleg használatban lévők, ehhez azonban már precízebb motorok kellenek.

\section{Stirling motor müködése}

A Stirling-motor vagy más néven hölégmotor külső hőbevezetésű hőerőgép, általában dugattyús-forgattyús mechanizmussal készül. A forgattyús mechanizmus folyamatos körmozgást folyamatos egyenesvonalú lengőmozgássá illetve egyenesvonalú lengőmozgást körmozgássá átalakító mechanizmus. A forgattyús mechanizmust a müszaki gyakorlatban igen sok helyen használják. Erőgépek és munkagépek esetén forgattyús hajtómünek is nevezik, mivel a mechanizmusnak ezekben az esetekben nemcsak kinematikai szerepe van, hanem energiaátadást is végez. A forgattyús mechanizmus (1. ábra) négy tagból álló síkbeli karos kinematikai lánc, melyből az egyik tag a merevnek tekintett talaj.

\section{1. ábra: Forgattyús mechanizmus [1]}

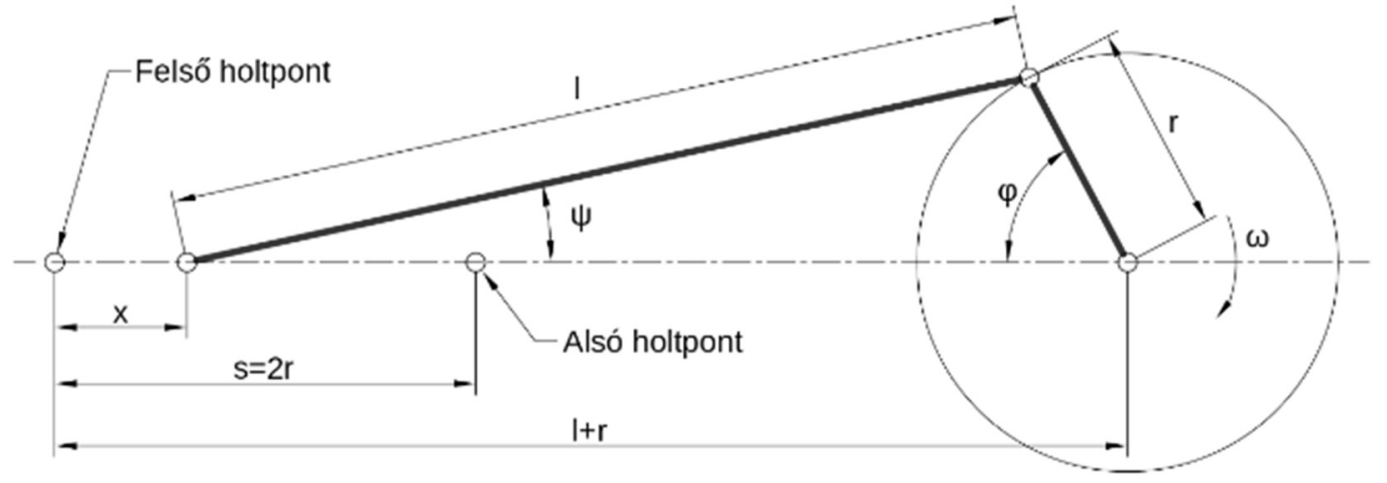

A forgattyús mechanizmus fő részei:

- Forgattyú: egy tengelyre szerelt vagy vele egy darabból készített kar. A kar és a tengely együttes neve forgattyústengely.

- A hajtórúd: egyenes rúd, mindkét végén csapágyazva, egyik csapágya a forgattyú csapjához, a másik a keresztfej csapjához illeszkedik.

- Keresztfej: egyenes vezetékben csúszó gépelem, melynek csapjára a hajtórúd másik csapágya csatlakozik. A keresztfej egyenesvonalú lengőmozgást végez. A keresztfejhez csatlakoztatják a gép azon részeit, melyek munkagépeknél munkavégzésre, illetve erőgépeknél energiaforrásként szolgálnak.

- Talaj, vagyis a szilárdnak tekintett alap vagy gépkeret, melyhez rögzített a forgattyústengely csapágya, a keresztfej illetve a dugattyú vezetéke.

- A forgattyús mechanizmus kinematikája, a keresztfej elmozdulása, sebessége és gyorsulása az idő, illetve a forgattyúskar szögének függvényében (2. ábra): 
- Elmozdulás

$$
x(t)=r+l-r \cos (\omega t)-l \sqrt{1-\lambda^{2} \sin ^{2}(\omega t)}
$$

- Sebesség

$$
v(t)=\frac{d x(t)}{d t}=r \omega \sin (\omega t)\left[1+\frac{\lambda \cos (\omega t)}{\sqrt{1-\lambda^{2} \sin ^{2}(\omega t)}}\right]
$$

- Gyorsulás

$$
\begin{aligned}
a(t)=\frac{d v(t)}{d t}= & r \omega^{2}\left[\cos (\omega t)+\frac{\lambda \cos ^{2}(\omega t)}{\sqrt{1-\lambda^{2} \sin ^{2}(\omega t)}}-\frac{\lambda \sin ^{2}(\omega t)}{\sqrt{1-\lambda^{2} \sin ^{2}(\omega t)}}\right. \\
& \left.+\frac{\lambda^{3} \cos ^{2}(\omega t) \sin ^{2}(\omega t)}{\left(1-\lambda^{2} \sin ^{2}(\omega t)\right)^{3 / 2}}\right]
\end{aligned}
$$

2. ábra: Geogebrában megrajzoltatott forgattyús mechanizmus $\boldsymbol{x}, \boldsymbol{v}, \boldsymbol{a}$ függvényei

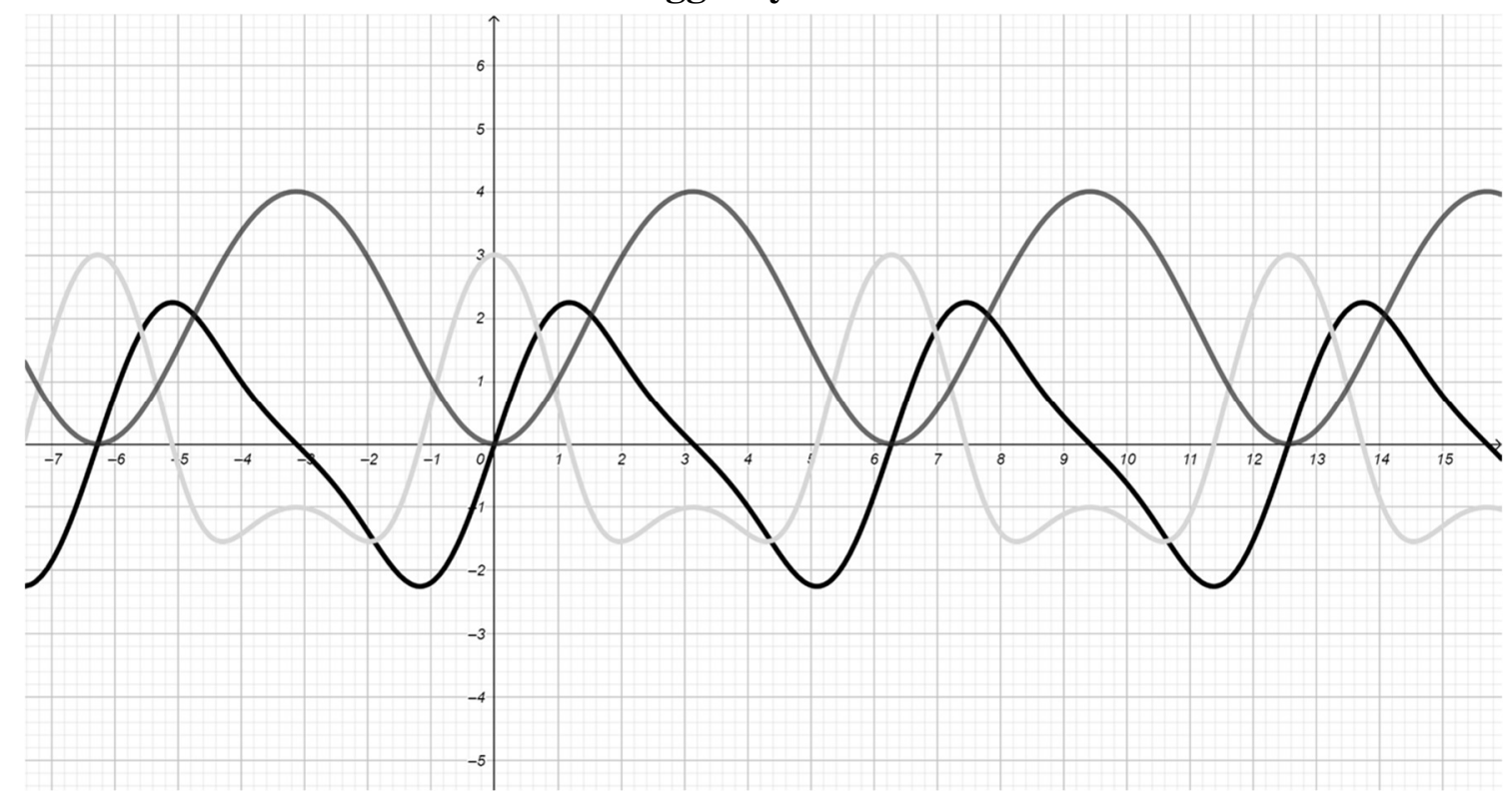

Forrás: A szerző saját szerkesztése.

A belsőégésủ motorokkal szemben a Stirling-motor hőforrása nem a hengerben elégő fütőanyag, mint az Otto- és Diesel-motoroknál vagy a gázturbinában, hanem a motoron kívül van. A hőátadási folyamat lehetővé teszi, hogy az összes hőerőgép közül a legjobb hatásfokot nyújtsa: hatásfoka megközelítheti annak az ideális Carnot-körfolyamatnak (3. ábra) a hatásfokát, amely az alkalmazott szerkezeti anyagoknál gyakorlatilag elérhető. A termikus hatásfokot a hőmérséklet határozza meg. Bármely körfolyamat hatásfoka, mely $T_{H}$ és $T_{C}$ hőmérsékletek között zajlik le, nem haladhatja meg a Carnot-körfolyamat hatásfokát. Carnot tétele a következő: Egyetlen hőerőgép, mely két hőtartály között üzemel, sem tud elérni jobb hatásfokot, mint az a Carnot-hőerőgép, mely ugyanezen két hőtartály között müködik. Egy 
hőerőgép elméletileg elérhető legnagyobb hatásfoka a meleg és hideg hőtartályok hőmérsékletkülönbsége (az abszolút hőmérséklet Kelvinben mérve egyenlö a Celsius-fokban megadott hőmérséklet plusz 273,15) osztva a meleg hőtartály hőmérsékletével:

$$
\eta=\frac{T_{H}+T_{C}}{T_{H}}
$$

A képletből észrevehető, ha a hideg tartály hőmérsékletét csökkentjü (4) jobban lehet növelni a hatásfokot, mint a meleg tartály hőmérsékletének emelésével. Ennek elérése a gyakorlatban nehézségekbe ütközik, mivel a hideg tartály hőmérséklete az esetek többségében egyszerüen az adott környezeti hőmérséklet.

\section{3. ábra: Carnot körfolyamat $\boldsymbol{p}-\boldsymbol{V}$ síkon [2]}

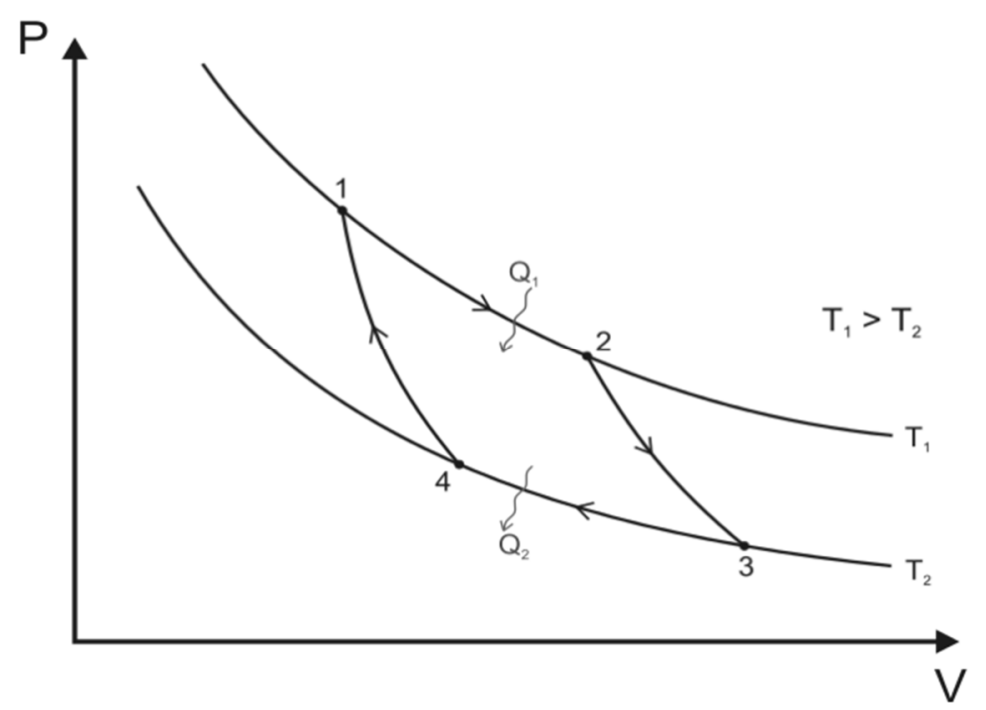

A Stirling-motorban egy adott tömegü, a környezettől tömítésekkel elzárt gáz, általában levegő, hidrogén vagy hélium van. Ennek a gáznak az állapotjelzői a gáztörvények szerint változnak. Amikor az adott térfogatú gázt melegítik, a nyomása megnő, és a dugattyú felületére hatva mechanikai munkát végez a motor munkaütemében. Amikor a gázt lehütik, nyomása esik, ez azt jelenti, hogy kevesebb munkára van szükség a gáz összenyomására a következő ütemben, mint amit a munkaütemben szolgáltatott, így az energiamérleg nyereséges lesz, ez a motor tengelyén hasznos munkaként fog megjelenni. A gáz ciklikusan áramlik a fütő és hütő hőcserélők között.

A gáz nem távozik a munkaütem után, hanem állandóan a motorban marad. Nincs szükség szelepekre sem, mint más motoroknál. Egyes Stirling-motorok külön dugattyút használnak a gáz áramoltatására a meleg és hideg kamrák között. Mások úgy kapcsolják össze a munkadugattyúkat a többhengeres motorokban, hogy megfelelően áramoltassák a gázt a különböző hőmérsékletű hengerek között. A gyakorlatban a Stirling-motorokban egy regeneratív alkatrészt, általában huzalok 
kötegét helyezik el a hideg és meleg hengerek közé. Ahogy a gáz áramlik a hideg és meleg kamrák között, höt ad vagy kap a regenerátortól. Egyes konstrukciókban a visszaáramoltató dugattyú maga a regenerátor. A regenerátor javítja a motor hatásfokát.

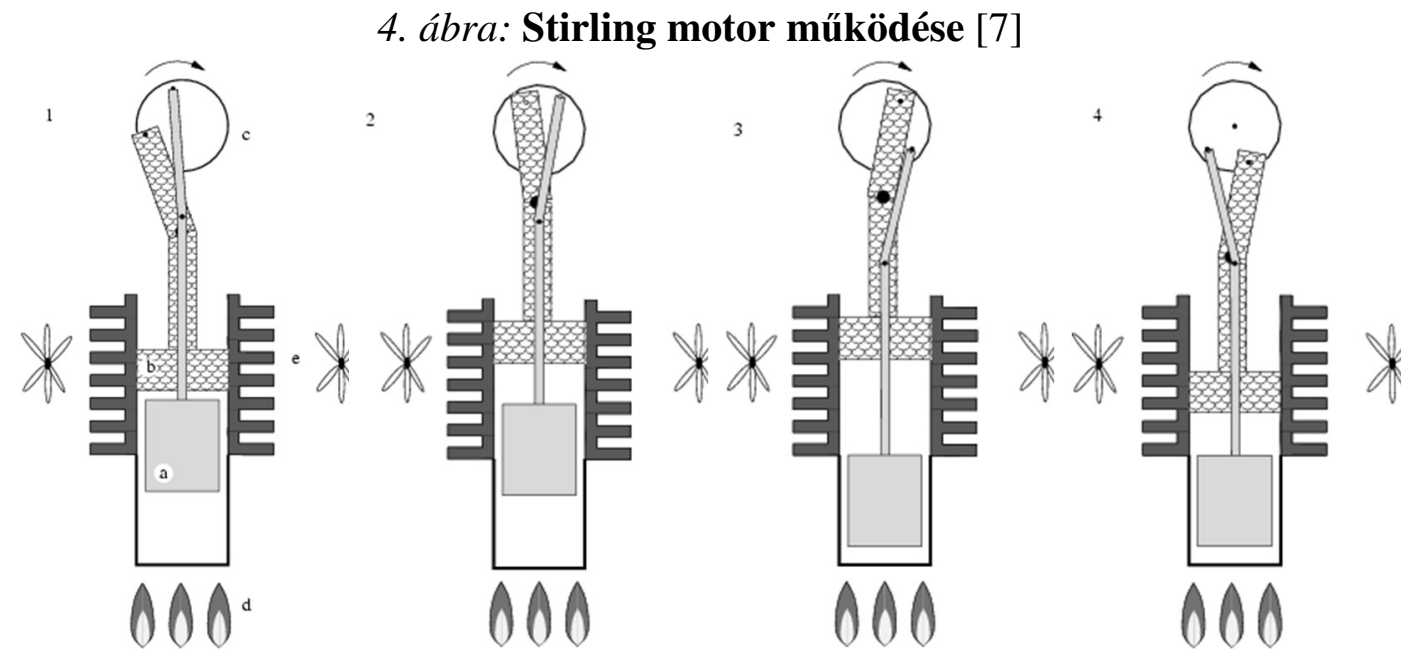

A Stirling-motor egyik változatának vázlata látható az ábrán.

- 1. ütemben Az alsó terelődugattyú alatti térben a gáz felmelegszik, kitágul és felfelé nyomja a munkadugattyút. Ez a munkaütem.

- 2. ütem az átáramoltatás, A felső holtpont után a terelődugattyú lefelé mozdul el, és átnyomja a gázt a hideg térbe, eközben a munkadugattyú még felfelé mozog, így a hütő henger térfogata nő.

- 3. ütemben a hideg kamrában lévő gáz fokozatosan lehül.

- 4. ütem A hideg gázt a terelődugattyú átnyomja a meleg hengerbe, és a folyamat kezdődik elölről.

\section{A Stirling-körfolyamat}

A Stirling-körfolyamat állandó térfogatú melegítési folyamatból, izotermikus tágulási folyamatból, állandó térfogatú hütési folyamatból és izotermikus összehúzódási folyamatból áll. A Carnot-körfolyamatnak a legjobb a hatásfoka. A Stirling-körfolyamat megfordítható, reverzibilis, azaz külső erővel hajtva hütőként is viselkedhet. A Stirling-motornál a gáz két, egymástól bizonyos távolságra lévő és különböző hőmérsékletű térben áramlik, és ez a hőmérsékletkülönbség nyomáskülönbséget hoz létre. Ez a két tér nagyon jól el van szigetelve a külső tértől, így nincs keveredés a külső tér levegöjével. A motor bárhol müködhet, ahol hőmérsékletkülönbség van jelen. 
5. ábra: Az ideális és valóságos Stirling-körfolyamat $\boldsymbol{p}$ - $\boldsymbol{V}$ diagramja [3]
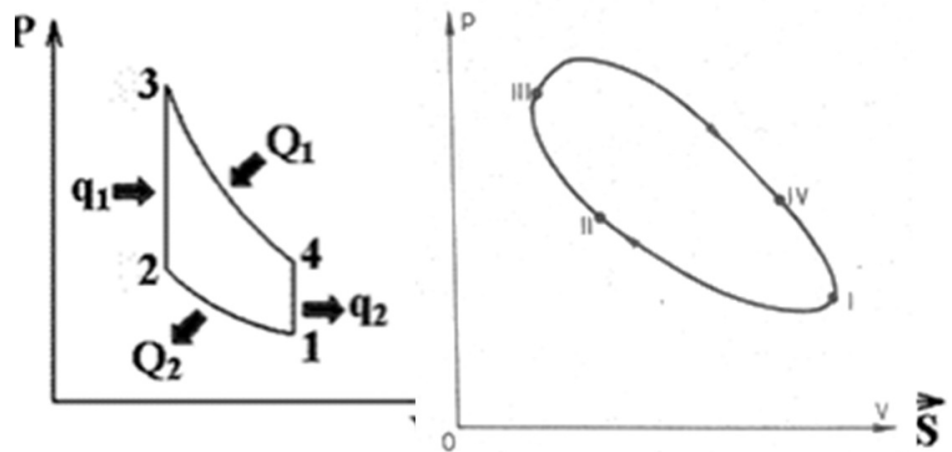

A munkafolyamat tehát négy, jól elkülöníthető fázisból áll:

- I-II izotermikus állapotváltozás (az állapotváltozás alatt a hőmérséklet állandó);

- II-III izochor állapotváltozás (az állapotváltozás alatt a térfogat állandó);

- III-IV izotermikus állapotváltozás;

- IV-I izochor állapotváltozás.

\section{Stirling motorok típusai:}

A mérnökök a Stirling-motor három fö típusát különböztetik meg:

\section{$4.1 \alpha$ típusú Stirling gép}

Az alfa Stirling változat két külön dugattyúval rendelkezik, egyik a meleg hőcserélőben, a másik a hideg hőcserélőben. Ennek a típusnak az egységnyi térfogatra eső teljesítménye nagy, de nehézségek merülnek fel a tömítéssel, mivel az egyik dugattyú állandó magas hőmérsékleten üzemel.

A dugattyúk közti fáziskülönbség $90^{\circ}$, melyet leggyakrabban a hengerek derékszögbe történő elforgatásával oldanak meg.

\section{6. ábra: Az $\alpha$ Stirling motor szerkezeti felépítése és munkaütemei [7]}
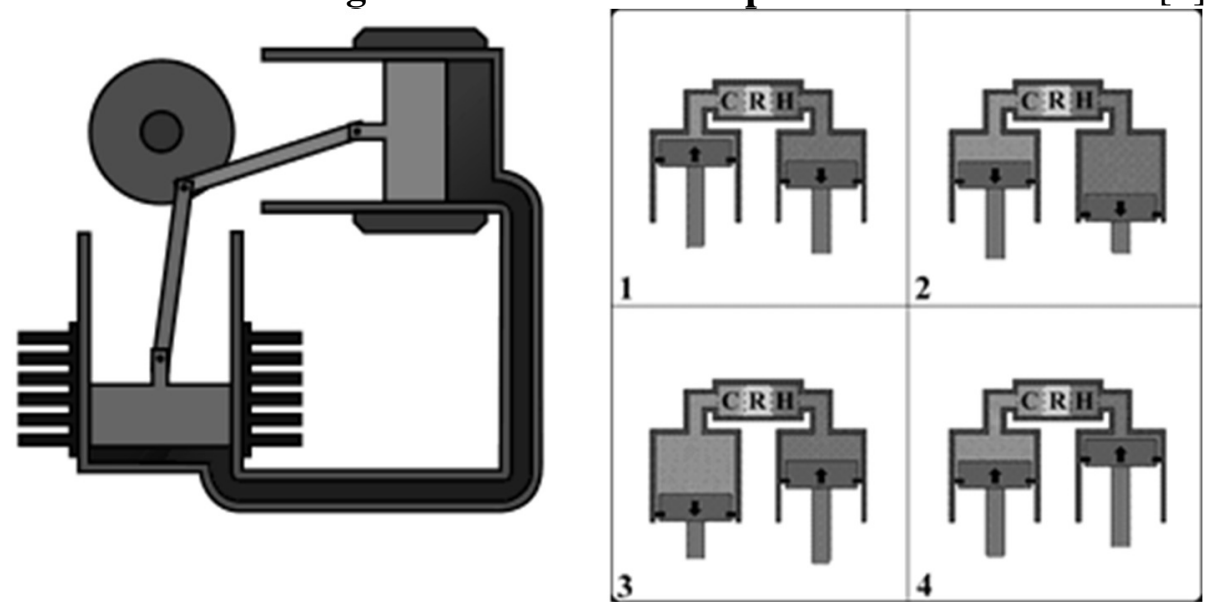
A C a hidegoldali hőcserélőt, az $\mathrm{R}$ a regenerátort, a $\mathrm{H}$ a melegoldali hőcserélőt jelöli.

\section{$4.2 \beta$ típusú Stirling gép}

A béta Stirling-motornak egyetlen hengerben egy terelődugattyúja és ezt körülvevő munkadugattyúja van, mely a terelődugattyúval egy tengely mentén mozog. A terelődugattyú hézaggal illeszkedik a hengerbe, nem szolgáltat hasznos munkát, csupán arra szolgál, hogy a gázt a forró kamrából a hideg kamrába tolja. Amikor eléri a meleg hengervéget (a gáz a hidegben van), a lendítőkerék kis késleltetéssel átsegíti a munkadugattyút a holtponton, amely megkezdi a hideg gáz komprimálását, és a terelődugattyú a gáz a meleg hengerbe átnyomását. Ez a konstrukció elkerüli az alfa változatnál felmerülő problémákat. Mivel azonban a kiszorító és munka dugattyú tengelyei egyvonalban helyezkednek el, ezért a készülék elkészítése nehézkes.

\section{7.ábra: A $\boldsymbol{\beta}$ Stirling motor szerkezeti felépítése és munkaütemei [7]}
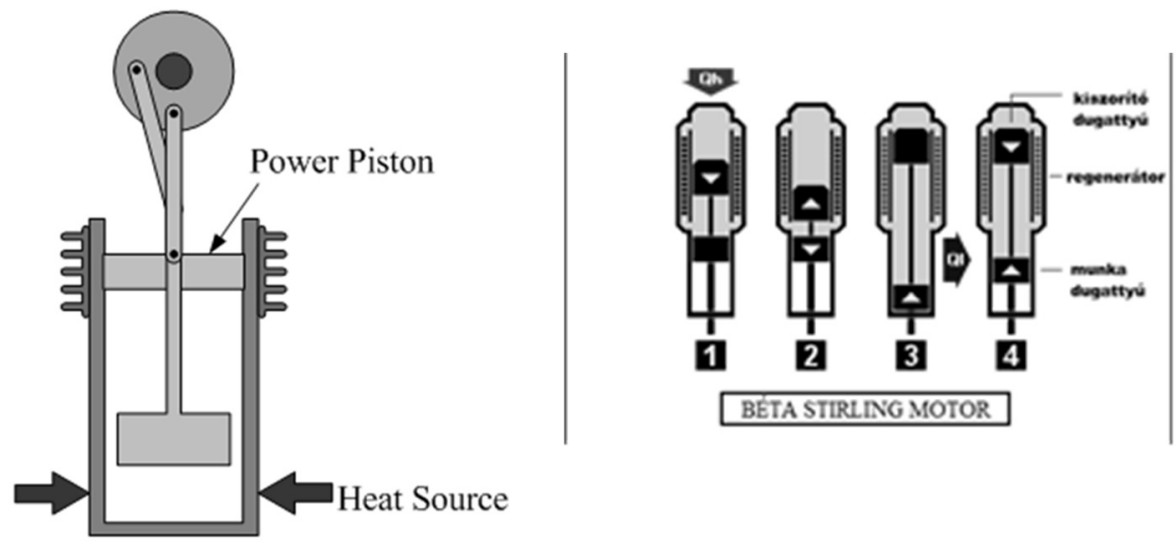

\section{$4.3 \gamma$ típusú Stirling gép}

A gamma Stirling-motor egyszerủen egy olyan béta változat, ahol a munkadugattyú és a terelődugattyú két különálló hengerben mozog, de mindkét forgattyú ugyanahhoz a forgattyús tengelyhez csatlakozik. A gáz a két henger között szabadon áramolhat. Ez a megoldás kisebb kompresszióviszonyt tesz lehetővé, de az elöbbieknél egyszerübb a szerkezete és gyakran használják többhengeres kiviteleknél. 
8. ábra: A $\gamma$ Stirling motor szerkezeti felépítése és munkaütemei [7]

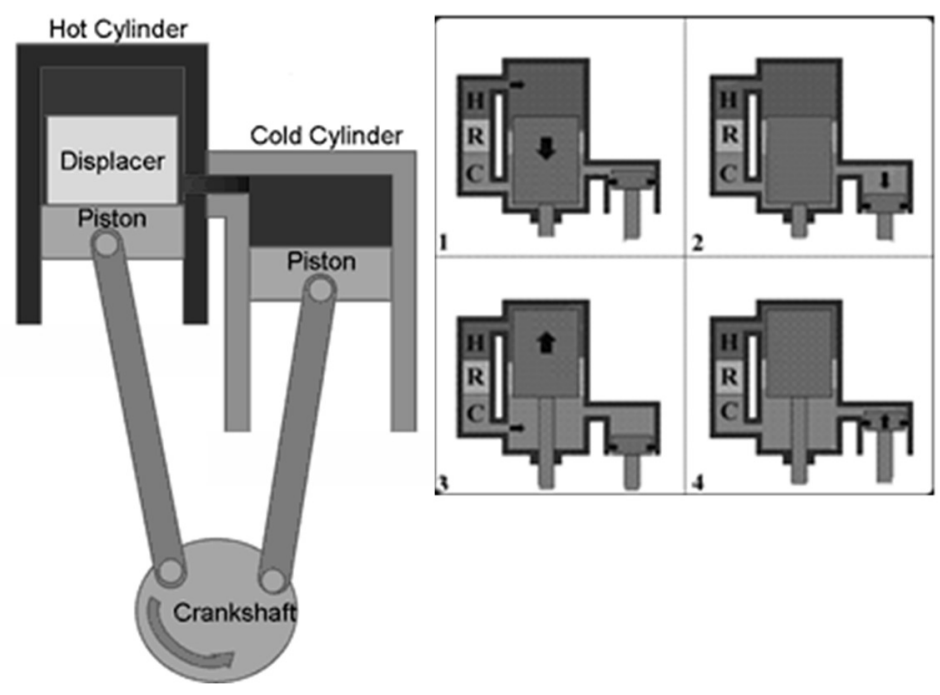

A C a hidegoldali hőcserélőt, az $\mathrm{R}$ a regenerátort, a $\mathrm{H}$ a melegoldali hőcserélőt jelöli.

\section{Stirling hütőgépek}

A Stirling-motor müködése megfordítható: ha a tengelyt forgatjuk, a kamrákon höfokkülönbség mérhető. A Stirling gép ilyenkor hőszivattyúként müködik. Leggyakrabban elektromos energia felhasználásával a munkadugattyú süríteni kezdi a gázt, mely eközben felmelegszik. A gáz megnövekedett hőmérsékletét elvonjuk, amivel akár füteni is lehet. Ezután a kiszorító dugattyú áttereli a gép hủtött oldalára a gázt, a munkadugattyú pedig visszatér a kiindulási helyzetébe. A gáz nyomása normalizálódik, közben kitágul az eredeti mértékben, de mivel az előző ciklusban höenergiát vontunk ki belőle, így annyival alacsonyabb hőmérsékletre hül le. A gépnek ezt a ciklusát így hütésre is fel lehet használni. Az első Stirling-hütőgépeket a Philips fejlesztette ki az 1950-es években és többek között cseppfolyós nitrogén gyártáshoz használták. Érzékelők hűtésére sokféle kis Stirling-hütőgépet használnak mai napig. A legmodernebb Stirling ciklusú gépek termoakusztikus elven müködnek.

A hagyományos Stirling hütőgépeknél több típust is használnak. Például a Stirling Cryogenics gépei 1, vagy 4 hengeresek. Képesek extrém alacsony hőfokot előállítani, -75-től, akár -250 Celsius fokig, így kiválóan lehet használni őket a gázok cseppfolyósítására.

\section{Történelmi adatok:}

- 1834 John Herschel Csillagász hütött először Stirling-géppel.

- 1849-ben a skót származású, de Dél-Karolinába (USA) kivándorolt John Gorrie, már jeget állított elő vele.

- 1876-ból Alexander Carnegie Kirk publikációjából kitünik, hogy akkoriban már szélesebb körben is ismerték a hütő technológiát. 
- A századfordulóra mégis, szinte teljesen feledésbe merültek a hideget előállító Stirling gépek, és csak 1940-ben, a Holland Philips cég karolja fel újra a technológiát.

- 1946-ban JWL Köhler Philips vezetésével gázt cseppfolyósítottak.

- 1964-ben, mikor William Beale, az Ohio egyetem professzora megalkotta szabad (free) dugattyús gépét.

- 1995-ben David Berchowitz, dél-afrikai mérnök, aki korábban dolgozott a Sunpowernél is elhatározta, hogy napenergiával müködő hütőt fog készíteni, de szem előtt tartja a valós felhasználói igényeket is. Megalapította saját cégét, a holland székhelyü Global Cooling Inc-t, és megkezdte a free Stirling hütők kereskedelmi forgalmazását.

- 2001-ben a szabad dugattyús Stirling hütőszekrények 30\%-kal kevesebb energiát használtak, egyharmaddal kisebb volt a súlyuk és nem tartalmaztak az ózonrétegre káros fluorozott szénhidrogéneket, mint a Rankine rendszerü hagyományos hütők.

\section{9. ábra: Az első free hütőgép, és egy kereskedelmi free Stirling hütőgép [7]}

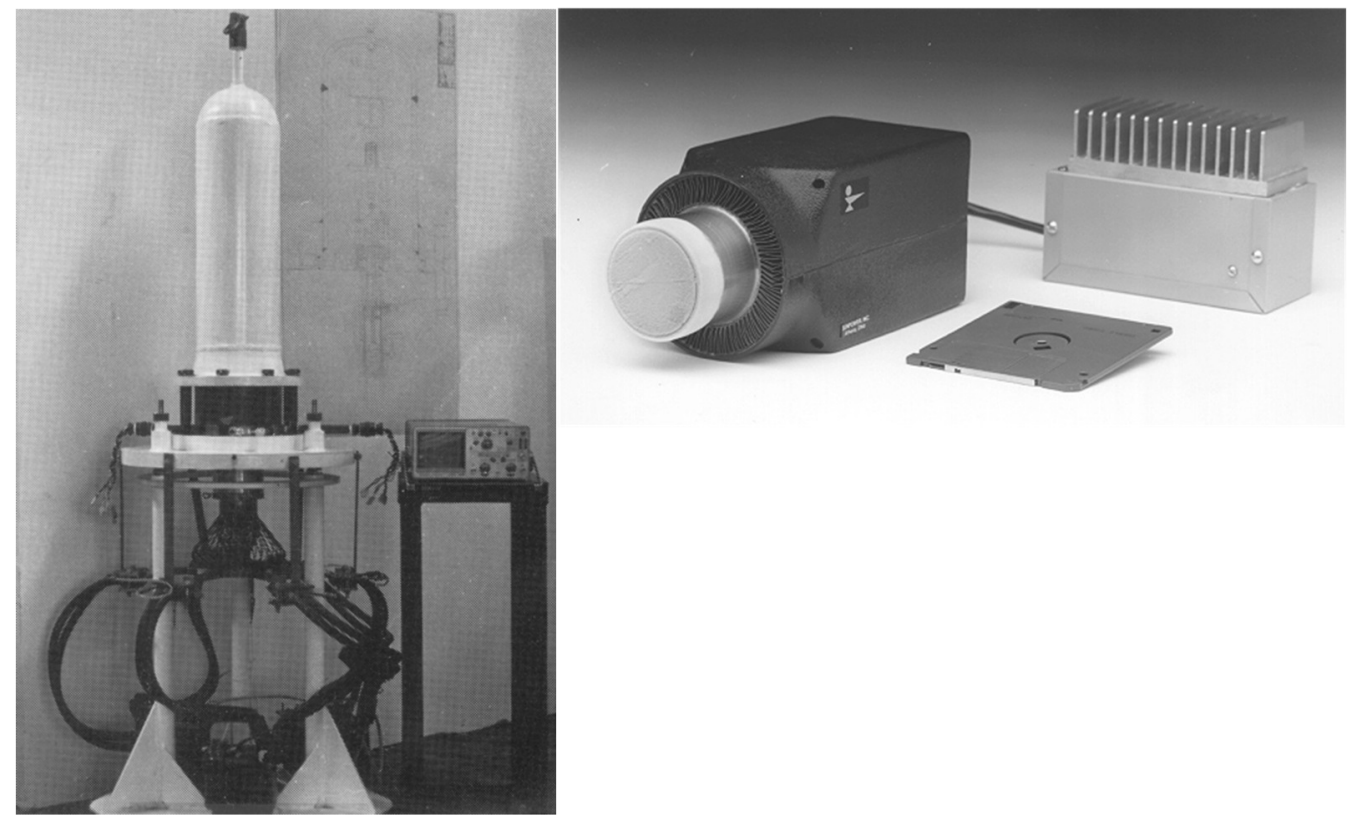

\section{Termoakusztikus múködési elv}

Hőenergiából állítunk elő igen erős hangot, gáz oszcillációjával, az rezegtet egy dugattyút vagy membránt, amely egy lineáris generátor segítségével elektromos energiát termel. Elérhető hatásfok állóhullámú gépnél kb. 8-20\% körül, de már kevésbé fejlesztik, mert a haladó hullámú (stirling-ciklusú) 1,5-2-szer jobb hatásfokú., így ezekkel 30-35\% feletti is elérhetö. Olyan hőlégmotorokat, stirling gépeket akarnak csinálni, amelyek kevesebb anyagot, és alkatrészt tartalmaznak, és egyszerübb a felépítésük. A free dugattyús stirling gépeknél látható, hogy el tudták 
hagyni a forgattyús szerkezeteket (lendkereket, hatókarokat, stb.), sőt olyan gépet is bemutattak, ahol a dugattyút, vagy dugattyúkat nem tömör szilárd anyagból, még csak nem is rugalmas membránból készítik, hanem folyadékból, vagyis vízdugattyúról beszélhetünk. Levegőből készítjük el a dugattyúkat, vagy persze olyan gázból, amivel megtöltjük a gépet. Ez nem túl bonyolult, hiszen, ha egy csőbe gáz van, akkor a benne lévő gáznak tömege és rugalmassága is van, gondoljunk csak egy autó gázrugó lengéscsillapítójára. Vagyis, ha egy csövet veszünk, akkor geometriailag rögtön kialakítottunk egy gázdugattyút benne, amit nem kellett a hengerhez pontosan esztergálni, nem kopik, nem korrodál, nem drága, de tartós.

\section{Stirling gépek előnyei}

- Az égés kívül zajlik le, ezért a levegö-tüzelőanyag-keveréket sokkal pontosabban lehet szabályozni.

- A hőforrás folytonos égést kíván, ezért az elégetlen füstgázok mennyisége elenyésző.

- Sok Stirling-motor csapágyazása a hideg oldalon helyezkedik el, ezért a kenést egyszerübb megoldani, és a kenőanyag élettartama két olajcsere között hosszabb lehet.

- Az egész motor sokkal kevésbé bonyolult szerkezet, mint a belsőégésü motorok. Nincsenek szelepek, illetve a tüzelőanyag- és beömlő rendszer is sokkal egyszerübb.

- Sokkal kisebb nyomáson üzemelnek, ezért sokkal biztonságosabbak, mint a konvencionális hőerőgépek.

- A kisebb üzemnyomás könnyebb szerkezeti elemek beépítését teszi lehetővé.

- Nagyon nyugodt járású szerkezetet lehet kivitelezni, működéséhez nincs szüksége külső levegőre, így tengeralattjárókon ideális erőgép lehet.

- Ígéretesnek tünik alkalmazása repülőgépeken: csendesebbek, kevésbé szennyezik a környezetet, megőrzik hatásfokukat a magasságtól függetlenül, megbízhatóbbak, mert kevesebb alkatrészből állnak, elmarad az indítóberendezés, kisebb rezgésszinten üzemelnek, az üzemanyaguk kevésbé robbanásveszélyes.

\section{Stirling gépek hátrányai}

- A Stirling-motor hideg és meleg oldali hőcserélői költséges szerkezetek, ezek nyomásálló és korrózióálló kivitelben kell, hogy készüijenek. Ez megnöveli a költségeket különösen akkor, ha jó hatásfokú motort kell készíteni.

- Különösen kis hőmérsékletkülönbség esetén a hideg és meleg oldal között a motor méretei sokkal nagyobbak az azonos teljesítményü belsőégésü motorokhoz képest a nagy hőcserélők miatt.

- A környezet felmelegítésekor keletkezö hőveszteség a legnagyobb akadálya annak, hogy Stirling-motorokat alkalmazzanak gépkocsi hajtására. Ez 
azonban nem hátrányos házaknál, ahol a hőveszteséget jól fel lehet használni melegvíz elöállítására és fütésre.

- A Stirling-motort nem lehet gyorsan beindítani, lassú felmelegedésre van szüksége. Ez ugyan a belsőégésü motorokra is igaz, de a felfütéshez szükséges idő itt sokkal hosszabb.

- A leadott teljesítményt nehéz változtatni, gyors változtatás nem is lehetséges. A teljesítményt vagy a dugattyú lökethosszának változtatásával vagy az áramló gáz mennyiségével lehet szabályozni. Ez hibrid hajtásokban és alaperőforrásoknál, ahol állandó teljesítményre van szükség, kevéssé problematikus.

- A hidrogént kis molekulasúlya ideális munkaközeggé teszi, de a hidrogént kicsi molekulái miatt nagyon nehéz zárt térben tartani szivárgás nélkül.

\section{9. Összefoglalás}

A Stirling gépekbe rejlő potenciált a haditechnológia, és az ürkutatás is kezdi felfedezni. A haditechnikába például a modern tengeralattjárókba építhető generátorok meghajtására. [7] Az ürkutatásban a létesítmények ellátására tervezik alkalmazni. Jövőbeli tervek között szerepel egy a tanszéken található stirling gép méréses vizsgálata, amely egy szíjhajtáson keresztül kapcsolódik egy generátorhoz.

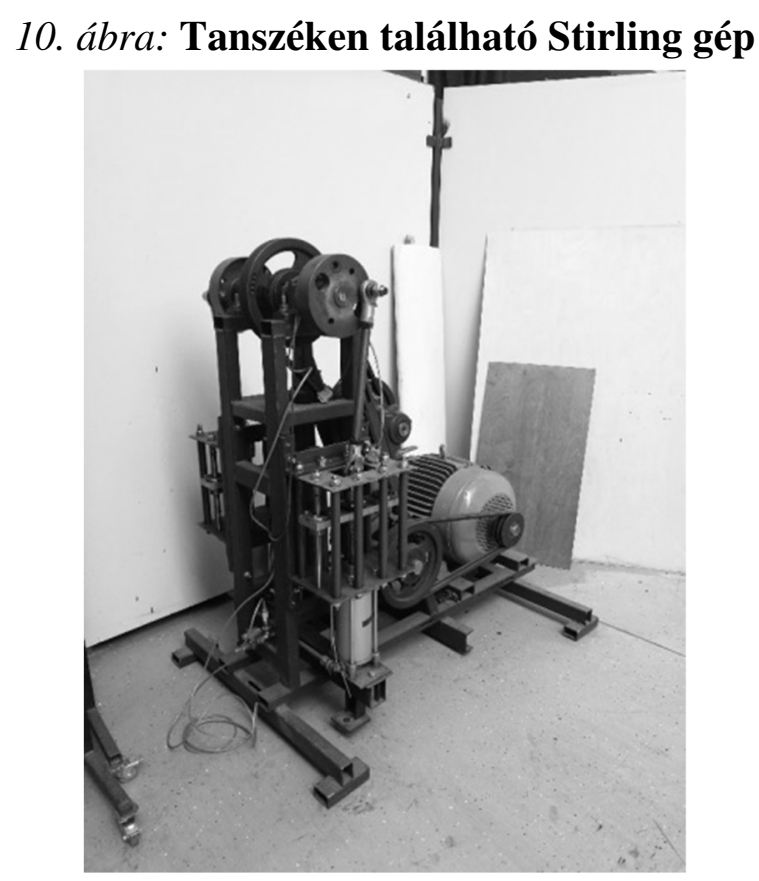

Forrás: A szerző saját szerkesztése.

\section{Köszönetnyilvánítás}

Az ismertetett kutató munka az EFOP-3.6.1-16-00011 jelü „Fiatalodó és Megújuló Egyetem - Innovatív Tudásváros - a Miskolci Egyetem intelligens szakosodást szolgáló intézményi fejlesztése" projekt részeként - a Széchenyi 2020 keretében - 
98• Mészáros K. M. - Pozsa Á. - Illés T. - Tollár S. - Tolvaj B. - Bencs P.

az Európai Unió támogatásával, az Európai Szociális Alap társfinanszírozásával valósult meg.

\section{Irodalomjegyzék}

https://hu.wikipedia.org/wiki/Forgatty\%C3\%BAs_mechanizmus(2019.03.02.) [1]

https://hu.wikipedia.org/wiki/Carnot-ciklus, (2019.03.02.) [2]

http://www.vilaglex.hu/Lexikon/Html/StirligM.htm, (2019.03.25.) [3]

llan J. Organ: The air engine, Woodhead Publishing Limited (2007) [4]

William R. Martini: Stirling Engine Design Manual, National Aeronautics and Space Administration, (2004) [5]

Roy Darlington and Keith Strong: Stirling and hot air engines, The Crowood Press Ltd. (2007) [6] https://stirlingtechnology.blogspot.com/2012/06/epitesi-szamitasok.html (2019.03.20) [7]

https://aerospaceamerica.aiaa.org/departments/space-nuclear-power-

seriously/?fbclid=IwAR3RKbEiuSmu1RKjzao2INF4EMUX91vbIYlLTAzOHkkj44OQRldNe FiqPaU (2019.03.25) [8] 